\title{
Responding to Wartime Sexual Violence: uN Peacekeeping and the Protection Agenda
}

\author{
Lisa Hultman \\ Uppsala University, Sweden \\ lisa.hultman@pcr.uu.se \\ Karin Johansson \\ Uppsala University, Sweden \\ karin.johansson@pcr.uu.se
}

\begin{abstract}
Recent years have seen an increased emphasis on protection of civilians and the problem of sexual violence. The Security Council has adopted a number of resolutions towards improving the status of women in the realm of peace and security. However, we do not know if this translates into action by the Security Council in terms of deploying peacekeepers to respond to sexual violence. In this paper, we examine to what extent the prevalence of sexual violence increases the likelihood that the UN chooses to deploy peacekeeping operations. In doing so, we acknowledge that sexual violence is an underreported phenomenon, about which the Security Council may not have perfect information. We explore this question by using data from the svac dataset in all intrastate armed conflicts, 1989-2009, which provides information about sexual violence as reported by three main agencies. We examine to what extent sexual violence, as reported by different agencies, is correlated with a higher likelihood that the UN deploys a peacekeeping operation. Our findings suggest that reports of sexual violence on average increase the likelihood of a peacekeeping operation. However, depending on which of the sources we consider, we find contradictory findings for whether the UN responds differently to sexual violence perpetrated by states and non-state actors respectively.
\end{abstract}

* Lisa Hultman acknowledges the generous research funding from Knut and Alice Wallenberg Foundation. The authors would also like to thank the organizers and participants of the Measuring Trends in Violence against Civilians workshop in Atlanta, 15 March 2016, for feedback on an early version of the paper. 


\section{Keywords}

peacekeeping - sexual violence - protection of civilians - UN Security Council

Over the last two decades there has been a growing expectation that the international community, and in particular the United Nations (UN), should react to and intervene to protect civilians when there is a risk for massive levels of violence against civilians. This is manifested in the UN Security Council authorization of the use of force to protect civilians and in the adopted principle of the Responsibility to Protect (R2P) by the General Assembly. ${ }^{1}$ With this emerging protection norm, there is a greater emphasis on civilian suffering in armed conflict. While civilian victimization for long has been conceptualized as deadly violence against civilians, there has been an increasing attention to sexual violence. A growing policy agenda together with several resolutions in the Security Council have emphasized the need to acknowledge and deal with such violence. ${ }^{2}$ The emphasis on civilian protection in UN peace operations should thus also encompass the protection from sexual violence. Nevertheless, we have very limited knowledge as to whether sexual violence in fact influences UN decisions to deploy peacekeepers.

In this paper we ask: Are UN peacekeeping operations more likely to be deployed when there are high levels of sexual violence? And does the UN respond differently to sexual violence perpetrated by states and non-state actors? In order to assess these questions we combine the Sexual Violence in Armed Conflict (sVAC) dataset ${ }^{3}$ with data on the deployment of un peacekeepers. ${ }^{4}$ Our sample has global coverage for the period 1989-2009 and includes all armed conflicts plus five post-conflict years. We also acknowledge the problem of measuring sexual violence. Systematic data sources on sexual violence are not only rare, but also incomplete due to underreporting. Hence, rather than

1 Alex J. Bellamy, Responsibility to Protect: The Global Effort to End Mass Atrocity (Cambridge: Polity Press, 2009); Charli R. Carpenter, "Women, Children, and Other Vulnerable Groups": Gender, Strategic Frames and the Protection of Civilians as a Transformational Issue', International Studies Quarterly, 49/2: 295-334 (2005); Siobhán Wills, Protecting Civilians: Obligations of Peacekeepers (Oxford: Oxford University Press, 2009).

2 Jana Krause, 'Revisiting Protection from Conflict-Related Sexual Violence: Actors, Victims and Power' in Theodora-Ismene Gizelis and Louise Olsson (eds.), Gender, Peace, and Security: Implementing un Security Council Resolution 1325 (London: Routledge, 2015).

3 Dara Kay Cohen and Ragnhild Nordås, 'Sexual Violence in Armed Conflict: Introducing the sVAC Dataset, 1989-2009', Journal of Peace Research, 51/3: 418-428 (2014).

4 Jake Kathman, 'United Nations Peacekeeping Personnel Commitments, 1990-2011', Conflict Management and Peace Science, 30/5:532-549 (2013). 
estimating the effect of the true levels of sexual violence, we estimate the effect of the information that is likely to be known to policy makers. We exploit the reporting from different sources in the SVAC dataset to examine whether our results change when we use one of the sources at the time.

Surprisingly, given the current policy discourse, our empirical analysis provides only weak evidence for a relationship between the intensity of reported sexual violence and the likelihood that the UN deploys peacekeepers. More sexual violence does, on average, increase the likelihood of un deployment, as we should expect from the increased emphasis on sexual violence within the UN. However, when we estimate separately the effect of sexual violence by states and non-state actors, most of the analysis suggests that it is mainly abuse by nonstate actors that leads to action by the UN Security Council. This is borne out in analyses using data on sexual violence as reported by both Amnesty International and Human Rights Watch. However, if we consider only sexual violence as reported by the us State Department, we find that only state violence is weakly correlated with UN peacekeeping. Apart from demonstrating an ambiguous relationship between sexual violence and the onset of UN peacekeeping operations, our analysis is a reminder of how difficult it is to measure sexual violence - and this is a challenge not only for a scholarly analysis, but also for policy makers that face poor information about on-going sexual violence.

In the next section we briefly present previous research on the determinants of peacekeeping operations, and after that we discuss the development of the policy agenda on the responsibility to protect and the parallel emphasis on women, peace, and security and protection from sexual violence. After that we present our data and research design, followed by the empirical analysis.

\section{Previous Research on Peacekeeping}

The main tool the UN has for physically protecting civilians from violence is peacekeeping. Explanations in previous research as to whether or not, and to what extent, the UN Security Council decides to deploy peacekeeping troops range from strategic to humanitarian. Focusing on the partiality of a majority of the UNSC members, one study finds that peacekeeping troops are deployed in greater numbers the more loss the preferred warring party experiences. ${ }^{5}$ That is to say that the Security Council is more prone to intervene when the government or rebel group that it supports experiences heavy military losses. Scholars have also identified a regional bias as to where peacekeepers are sent.

5 Michelle Benson and Jacob D. Kathman, 'United Nations Bias and Force Commitments in Civil Conflicts', Journal of Politics, 76/2: 350-363 (2014). 
While conflicts in Asia and in former colonies of the permanent members of the Security Council are least likely to receive peacekeeping assistance, conflicts in the Western hemisphere and Europe are more likely. ${ }^{6}$ Moreover, there seems to be a lower propensity to intervene in conflicts in major powers. ${ }^{7}$

Moving on to humanitarian concerns, the peacekeeping literature has shown that the UN historically has been more likely to intervene into so-called "hard cases" in terms of conflict intensity ${ }^{8}$ and relatively strong rebel groups. ${ }^{9}$ The ambition to protect civilians from harm has held up to scrutiny in several empirical examinations. Indeed, peacekeeping operations are more likely in conflicts with high levels of violence against civilians ${ }^{10}$ and where the risk of genocide is high. ${ }^{11}$ This willingness to take action in response to civilian atrocities has increased over time in parallel with the increased emphasis on civilian protection..$^{12}$ In these regards, there is a clear distinction between peacekeeping operations mandated by the UN and other forms of military interventions, which are more likely to take place in low-intensity conflicts. ${ }^{13}$

\section{Responsibility to Protect - Also from Sexual Violence?}

Recent decades have seen an increase in the focus on civilian victimization in war and the international community's responsibility to protect. ${ }^{14}$ Much in response to the civilian atrocities in Bosnia, Somalia, and Rwanda, the scope of international security has broadened from primarily focusing on security of the nation state to encompass issues of human security. While the potential

6 Virginia Page Fortna, Does Peacekeeping Work? Shaping Belligerents'Choices after Civil War (Princeton: Princeton University Press, 2008); Michael Gilligan and Stephen John Stedman, 'Where Do the Peacekeeper Go?' International Studies Review, 5/4: 37-54 (2003).

Mark J. Mullenbach, 'Deciding to Keep Peace: An Analysis of International Influences on the Establishment of Third-Party Peacekeeping Missions', International Studies Quarterly, 49/3: 529-555 (2005).

$8 \quad$ Gilligan and Stedman, 'Where Do the Peacekeepers Go?'

$9 \quad$ Fortna, Does Peacekeeping Work?

10 Lisa Hultman, 'UN Peace Operations and Protection of Civilians: Cheap Talk or Norm Implementation?' Journal of Peace Research, 50/1: 59-73 (2013).

11 Erik Melander, 'Selected To Go Where Murderers Lurk? The Preventive Effect of Peacekeeping on Mass Killings of Civilians', Conflict Management and Peace Science, 26/4: 389-406 (2009).

12 Hultman, 'UN Peace Operations'.

13 Cf. Patrick M. Regan, 'Third-party interventions and the duration of intrastate conflicts', The Journal of Conflict Resolution, 46/1: 55-73 (2002).

14 Bellamy, Responsibility to Protect; Carpenter, 'Women, Children'; Wills, Protecting Civilians. 
to intervene out of humanitarian concerns was discussed throughout most of the 1990s, it was not until 1999 that the UNSC explicitly mandated a mission to protect civilians (for UNAMSIL in Sierra Leone).

Alongside the strengthened norm of civilian protection, there has been an increased focus on the use of sexual violence in armed conflict and the need for proactive measures to protect civilians from sexual abuse. Following persistent lobbying from NGOs and a small group of member states, the UNSC issued its first resolution including stipulations about sexual violence in 2000, in UNSCR1325 on Women, Peace, and Security. ${ }^{15}$ This foundational resolution covers a wide range of gender equality matters, revolving around three pillars: Women participation/representation in decision-making processes; Gender mainstreaming, for example in planning and execution of peacekeeping missions; and Protection of women from conflict-related sexual and gender-based violence. ${ }^{16}$ Followed by another seven UN resolutions over the last 15 years, combined with an increasing number of national action plans, this marks a normative development which could be described as "linear". ${ }^{17}$ While participation arguably is at the core of the Women, Peace, and Security framework, much attention has indeed focused on protection. Four out of the seven follow-up resolutions are primarily dedicated to prevention and protection from sexual and/or gender-based violence. ${ }^{18}$ There is also a clear emphasis on conflict-related sexual violence in the country reports on Women, Peace and Security to the unsc. ${ }^{19}$ As it appears, it has been comparatively easier to come to agreement on policies related to the physical violence than on other, more culturally disputed aspects of gender equality. Indeed, UNSCR1325 has been widely criticized for reflecting a Western/Nordic understanding of gender equality ${ }^{20}$ - an unsettled disagreement that remains a challenge within the UNSC to this day. ${ }^{21}$

The narrow focus on gender-based and/or sexual violence is also evident in core documents on the Responsibility to Protect (R2P). Despite obvious areas

\footnotetext{
15 UnSC Res. 1325, 31 October 2000.

16 Torunn L. Tryggestad, 'F N som normspreder: Kvinner, fred og sikkerhet', Internasjonal Politikk, 72/2: 275-284 (2015).

17 Tryggestad, 'FN som normspreder', p. 278.

18 Paul Kirby and Laura J Shepherd, 'The Futures Past of the Women, Peace and Security Agenda', International Affairs, 92/2: 373-392 (2016); Tryggestad, 'FN som normspreder'.

19 Kirby and Shepherd, 'The Futures Past'.

20 Inger Skjelsbæk, 'Responsibility to Protect or Prevent? Victims and Perpetrators of Sexual Violence Crimes in Armed Conflicts', Global Responsibility to Protect, 4/2: 154-171 (2012); Torunn L. Tryggestad, 'Trick or Treat? The UN and Implementation of Security Council Resolution 1325 on Women, Peace, and Security', Global Governance, 15/4: 539-557 (2009). Tryggestad, 'FN som normspreder'.
} 
of mutual interests, ${ }^{22}$ there are no explicit references to the wider Women, Peace, and Security agenda in the original report by the International Commission on Intervention and State Sovereignty (ICISS) on R2P, which was issued one year and two months after UNSCR1325 was adopted. Two out of the three times women are mentioned in the report, they are discussed as victims of rape. The ICISs stipulates that rape may be a cause of intervention if employed as a means of ethnic cleansing. ${ }^{23}$ The World Summit in 2005 stipulates that R2 P should apply to cases of genocide, war crimes, ethnic cleansing and crimes against humanity. ${ }^{24}$ Given the jurisprudence of the International Courts in Rwanda and former Yugoslavia where sexual violence was considered a crime against humanity, ${ }^{25}$ this affirms the applicability of sexual violence to the R2P principles. The link is made explicit in the Secretary General's report in 2009. ${ }^{26}$

From the wider perspective of Women, Peace, and Security, there are many reasons for concern about this narrow focus on sexual and gender-based violence. ${ }^{27}$ As the focus of this paper is on sexual violence, we do however not engage with this critique further. Instead we note that if any topic related to the gendered dimensions of war should have bearing on the deployment of peacekeeping troops, it ought to be sexual violence.

The Department of Peacekeeping Operations (DPKO) was one of the first UN bodies to implement changes according to UNSCR1325 by ensuring gender advisors (or equivalent) being part in every mission since the year 2000. Policy Directives have been adopted which include clauses on safety in relation to gender-based violence. ${ }^{28}$ In 2009, the UNSCR 1888 mandated the deployment of women's protection advisors to conflict areas with reported problems of sexual violence. ${ }^{29}$ If there is no discernable correlation between reports of sexual violence and the deployment of peacekeeping troops, we may have reasons to be worried about the overall receptiveness of the UNSC

Sarah Hewitt, 'Overcoming the Gender Gap: The Possibilities of Alignment between the Responsibility to Protect and the Women, Peace and Security Agenda', Global Responsibility to Protect, 8/1: 3-28 (2016).

International Commission on Intervention and State Sovereignty, The Responsibility To Protect (Ottawa: International Development Research Centre, 2001), p. 32.

24 '2005 World Summit Outcome', UNGA. Res. 6o/1, 16 September 2005, p. 30.

25 UNSC Res. 955, 8 Nov 1994; UNSC Res. 827, 25 May 1993.

26 Eli Stamnes, 'The Responsibility to Protect: Integrating Gender Perspectives into Policies and Practices', Global Responsibility to Protect, 4/2: 172-197 (2012), pp. 176-177; s/2009/362, 20 August 2009, p. 2.

27 See e.g. Skjelsbaek, 'Responsibility to Protect', p. 163.

28 DPKо/DFs, 'Policy: Gender Equality in UN Peacekeeping Operations', 26 July 2010.

29 UNSC Res. 1888, 30 September 2009. 
on gender-related affairs. In this regard, our empirical examination could be seen as a test of the necessary but not sufficient integration of UNSCR1325 in peacekeeping policies.

To recall, in this paper we are interested in whether the observed emphasis on protection translates into a higher willingness by the Security Council to deploy peacekeeping missions when there are high levels of reported sexual violence. The UNSCR1325 has led to a fast norm development, emphasizing gender mainstreaming, inclusion of women in peace processes, and protection needs. However, as Olsson and Gizelis note, '[n]ormative wordings in documents and strong speeches, however, do not automatically translate into concrete actions and results'. ${ }^{30}$ For example, the number of female peacekeepers has increased over time. However, they are not sent to the places where they could be particularly needed, namely to places where sexual violence and gender equality has been a problem and where the deployment of female peacekeepers could have a positive impact. ${ }^{31}$ Despite this, the increased focus on UNSCR1325 and civilian protection in general, may push the Security Council to take action when there are reports about high levels of sexual violence in a conflict. The protection language of UN peacekeeping mandates often includes a sentence about protection from sexual or gender-based violence. ${ }^{32}$ This indicates that sexual violence is part of the discussion when UN peacekeeping missions are authorized. While it thus remains an open question whether the Security Council is more inclined to react when there are high levels of sexual violence, we formulate the following hypothesis to assess this potential relationship:

$\mathrm{HI}$ : The more reports of sexual violence there are from an armed conflict, the more likely that the UN deploys a peacekeeping operation.

\section{Research Design}

We examine the relationship between peacekeeping and sexual violence for all countries with internal armed conflict, 1989-2009. Internal armed conflicts

$30 \quad$ Louise Olsson and Gizelis, 'An Introduction to Resolution 1325: Measuring Progress and Impact', in Gizelis and Olsson (eds.), Gender, Peace, and Security, p. 1.

31 Sabrina Karim and Kyle Beardsley, 'Female Peacekeepers and Gender Balancing: Token Gestures or Informed Policymaking?' International Interactions, 39/4: 461-488 (2013).

32 Victoria K. Holt and Glyn Taylor, Protecting Civilians in the Context of UN Peacekeeping Operations: Successes, Setbacks and Remaining Challenges (New York: United Nations, 2009). 
are defined as an incompatibility between a government and one or more rebel groups that result in at least 25 battle-related deaths in a year, as identified in the UCDP/PRIO Armed Conflict Dataset. ${ }^{33}$ We observe these conflict countries annually for the duration of the active conflict plus up to five interim years if the conflict is temporarily inactive. We also add five post-conflict years, since sexual violence may continue during the post-conflict period and peacekeeping operations commonly are deployed to manage this transition to peace.

Our main dependent variable is the initial deployment of a peacekeeping operation to a conflict. We construct this using peacekeeping data from Kathman, noting the first year troops were deployed. ${ }^{34}$ The subsequent years of UN peacekeeping deployment are dropped from the analysis.

Data on sexual violence comes from the Sexual Violence in Armed Conflict dataset. ${ }^{35}$ The dataset contains information on the levels of sexual violence per conflict-actor-year (and the five post-conflict years that we include in our analysis) as reported in three separate sources: Us State Department Reports (USSD), Amnesty International (AI), and Human Rights Watch (HRW). In our analysis, we aggregate the data to the country-level and create three different types of variables. First, we collapse the three sources and use the maximum value for each observation. The variable ranges from o to 3 . A value of o represents 'no reports' of sexual violence; 1 represents 'isolated reports' of sexual violence; 2 represents reports of 'widespread' sexual violence and; 3 represents reports of sexual violence as 'massive'. Hence, our first variable Sexual Violence is a measure of the prevalence of sexual violence that goes from o to 3 according to any of the SVAC sources. Second, we disaggregate this variable by type of perpetrator into: $s v$ Government and $s v$ Rebels. Third, we use separate variables for the three different sources - hence, measuring sexual violence as reported by USSD, AI, and $\mathrm{HRW}$ respectively.

We include a number of control variables that may influence the deployment of peacekeepers or the occurrence of sexual violence. First, we account for the intensity of the conflict by including Battle-Related Deaths, which is a count of the number of persons killed in the conflict each year. These data come from the UCDP Battle-Related Violence Dataset, and we use the natural $\log$ of the count. ${ }^{36}$ Second, in some models we also control for lethal violence

Nils Petter Gleditsch, Peter Wallensteen, Mikael Eriksson, Margareta Sollenberg, and Håvard Strand, 'Armed Conflict 1946-2001: A New Dataset', Journal of Peace Research, 39/5: 615-637 (2002).

36 Erik Melander, Therése Pettersson, and Lotta Themnér, 'Organized violence, 1989-2015', Journal of Peace Research, 53/5: 727-742 (2016); UCDP Battle-Related Deaths Dataset v.52015, www.ucdp.uu.se/downloads/, accessed 9 February 2016. 
against civilians. Our variable One-Sided Violence is a count of the number of civilians directly and deliberately killed by an organized actor in the country that year. These data come from the UCDP One-Sided Violence Dataset. ${ }^{37}$ Third, we control for the type of incompatibility of the conflict. The variable Government conflict is a dummy variable for whether there is a conflict where the rebels challenge the power of central government (rather than claiming authority over a particular territory). This is defined by the UCDP/PRIO Armed Conflict Dataset. ${ }^{38}$

To account for the fact that the UN is more likely to intervene when rebels are relatively strong ${ }^{39}$ and that the relative strength may also influence the likelihood of sexual violence, we include Rebel strength. This variable is an ordinal variable ranging from 1 (much weaker) to 5 (much stronger), taken from the Non-State Actor Dataset. ${ }^{40}$ When there are multiple rebel groups, we code the maximum value that any group has that year. The peacekeeping literature has shown that peacekeeping missions are less likely to be deployed in large countries. ${ }^{41}$ Sexual violence, like other forms of political violence, may also be more likely the larger the population. Therefore, we include the natural log of the size of the Population, with data provided by the UN. ${ }^{42}$ Finally, we include a dummy variable separating between observations before and after 2000, which could be seen as a watershed in terms of attention within the Security Council to protection from sexual violence through UNSCR1325. Moreover, reporting of human rights abuses, including sexual violence, has likely increased over time. ${ }^{43}$

\section{Empirical Analysis}

The total number of peacekeepers deployed to on-going conflicts and initial post-conflict situations has varied a lot over the last decades. Figure 1 shows

37 Kristine Eck and Lisa Hultman, 'One-Sided Violence Against Civilians in War: Insights from New Fatality Data', Journal of Peace Research, 44/2: 233-246 (2007).

38 Gleditsch et al., 'Armed Conflict 1945-2001'.

39 Fortna, Does Peacekeeping Work?

40 David Cunningham, Kristian Gleditsch, and Idean Salehyan, 'It Takes Two: A Dyadic Analysis of Civil War Duration and Outcome', Journal of Conflict Resolution, 53/4: 570-597 (2009).

$41 \quad$ Gilligan and Stedman, 'Where Do the Peacekeepers Go?'

42 United Nations. 'The National Accounts Main Aggregates Database', 2015, http://unstats. un.org/unsd/snaama/Introduction.asp, accessed on 23 Feb 2016.

43 Cf. Christopher J. Fariss, 'Respect for Human Rights has Improved Over Time: Modeling the Changing Standard of Accountability', American Political Science Review, 108/2: 297318 (2014). 


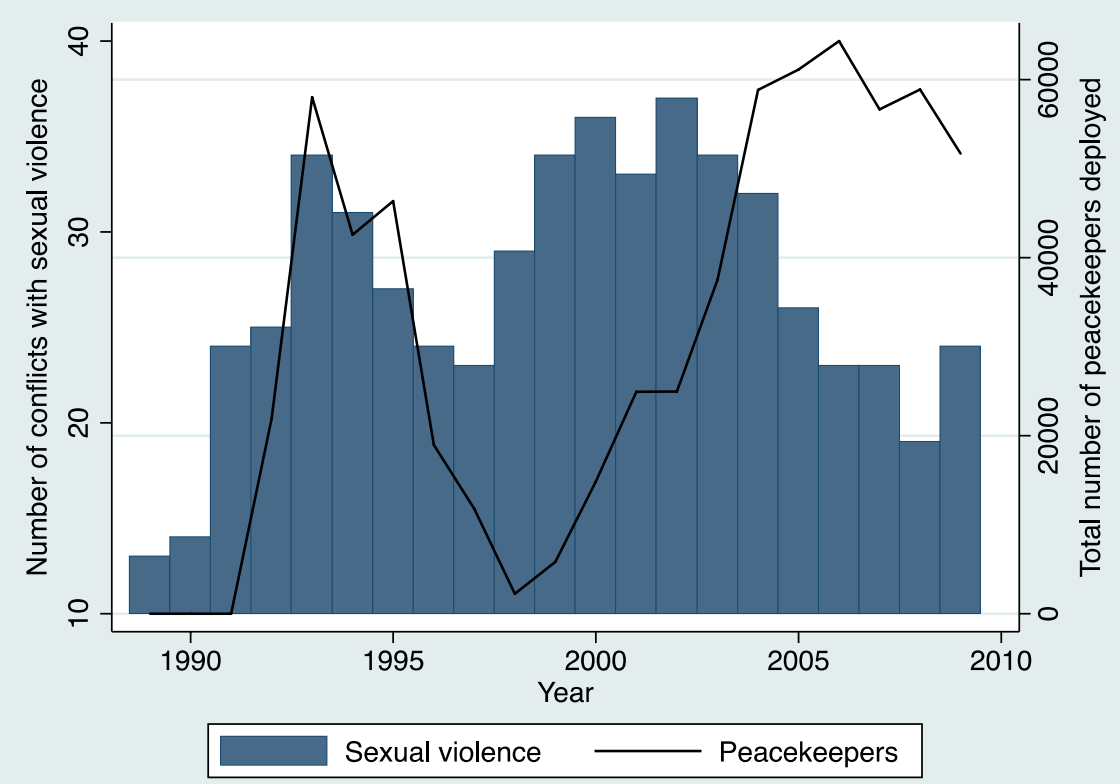

FIGURE 1 Global trend in sexual violence and the number of peacekeepers

the trend in the occurrence of sexual violence and peacekeeping deployment. Both of these have varied over this time period. In the early to mid-199os, there was a peak in both sexual violence and deployed peacekeepers. The high number of peacekeepers was mainly driven by the large operations in the Balkans. By looking at these early trends, it looks like there is a correlation. However, this early period was followed by a backlash in UN peacekeeping. After the failures in Bosnia, Rwanda, and Somalia, there was a sharp drop in UN involvement in active conflict settings. Reports of sexual violence did not decline as much and in the late 1990s and the early 2000 s there was a second peak in sexual violence that was not accompanied by an immediate rise in peacekeepers. However, eventually UN involvement in internal conflicts started to rise again and quite drastically so. This recent rise in peacekeeping presence has also coincided with a decline in reported sexual violence.

In our dataset of countries involved in armed conflict, we have a total of 974 observations, which corresponds to annual observations of conflict countries. Of these, 404 see some level of sexual violence. The majority of those cases are low levels of sexual violence: 30 percent of all the instances of sexual violence reflect widespread or massive sexual violence (prevalence level 2 and 3 ), while the other 70 percent are cases with isolated reports (prevalence level 1). What 


\begin{tabular}{lll}
\hline & Number of cases & $\begin{array}{l}\text { Percent of all cases } \\
\text { of sexual violence }\end{array}$ \\
\hline Any sexual violence & 19 & $6 \%$ \\
Sv by state actors & 15 & $6 \%$ \\
Sv by PGMs & 13 & $4 \%$ \\
sv by rebels & 11 & $9 \%$ \\
\hline
\end{tabular}

we are most interested in here is the overlap between sexual violence and peacekeeping operations. By looking at the data, we can say that peacekeepers do not deploy to all those cases of sexual violence. In total, only 20 percent of all conflict observations have a peacekeeping operation deployed. If we only look at conflict-years with sexual violence, peacekeeping operations are deployed in 20 percent also in these. Hence, peacekeeping is not more common when there is sexual violence. Perhaps more interesting, however, is to look at the correlation between sexual violence and initial deployment of a peacekeeping operation. Table 1 shows the number of peacekeeping operations being initiated, given that there were reports of sexual violence in the year prior. This happened in 19 instances, or $6 \%$ of the cases where sexual violence occurred and a UN peacekeeping mission thus was potentially warranted. Note that these are annual observations, which means deployment in $6 \%$ of the country-years with sexual violence - not in $6 \%$ of the countries. When breaking it down by the type of perpetrator, we find similar figures although with some variation. PKOs were most common when states were the perpetrators, but if we look at the PKO initiations relative to the number of cases, the UN response occurred most often in relation to sexual violence perpetrated by non-state actors.

In order to say anything beyond how these variables overlap, we move to a logistic regression estimating the impact of reported sexual violence on the likelihood that a UN peacekeeping operation is deployed. The results are reported in Table 2. We find that, on average, the severity of reported sexual violence increases the likelihood of a UN intervention. Using Clarify to calculate predicted probabilities ${ }^{44}$ we find that the likelihood of a UN peacekeeping operation being deployed to a country is $13 \%$ if there are reports of high levels

44 Michael Tomz, Jason Wittenberg, and Gary King, 'CLARIFY: Software for Interpreting and Presenting Statistical Results', Journal of Statistical Software 8 (2003). 


\begin{tabular}{|c|c|c|c|}
\hline Variables & $\begin{array}{c}(\mathbf{1}) \\
\text { UN PKO }\end{array}$ & $\begin{array}{c}(2) \\
\text { UN PKO }\end{array}$ & $\begin{array}{c}(3) \\
\text { UN PKO }\end{array}$ \\
\hline Sexual violence $_{t-1}$ & $\begin{array}{c}0.477^{* *} \\
(0.208)\end{array}$ & $\begin{array}{c}0.327 \\
(0.242)\end{array}$ & \\
\hline State sexual violence ${ }_{t-1}$ & & & $\begin{array}{c}0.376 \\
(0.229)\end{array}$ \\
\hline Rebel sexual violence $_{t-1}$ & & & $\begin{array}{c}0.412^{*} \\
(0.221)\end{array}$ \\
\hline One-sided violence $_{t-1}$ & & $\begin{array}{c}0.182^{*} \\
(0.101)\end{array}$ & \\
\hline Battle deaths ${ }_{t-1}$ & $\begin{array}{c}0.141 \\
(0.0967)\end{array}$ & $\begin{array}{c}0.0572 \\
(0.105)\end{array}$ & $\begin{array}{c}0.130 \\
(0.0939)\end{array}$ \\
\hline Population & $\begin{array}{c}-0.137 \\
(0.166)\end{array}$ & $\begin{array}{c}-0.173 \\
(0.169)\end{array}$ & $\begin{array}{c}-0.13^{2} \\
(0.168)\end{array}$ \\
\hline Government conflict & $\begin{array}{c}0.489 \\
(0.470)\end{array}$ & $\begin{array}{c}0.45^{2} \\
(0.469)\end{array}$ & $\begin{array}{c}0.448 \\
(0.482)\end{array}$ \\
\hline Rebel strength & $\begin{array}{l}0.549^{* * *} \\
(0.209)\end{array}$ & $\begin{array}{l}0.479^{* *} \\
(0.204)\end{array}$ & $\begin{array}{l}0.543^{* * *} \\
(0.210)\end{array}$ \\
\hline Post-200o & $\begin{array}{c}-0.259 \\
(0.444)\end{array}$ & $\begin{array}{c}-0.216 \\
(0.440)\end{array}$ & $\begin{array}{c}-0.292 \\
(0.447)\end{array}$ \\
\hline Constant & $\begin{array}{l}-3.280 \\
(2.722)\end{array}$ & $\begin{array}{l}-2.573 \\
(2.722)\end{array}$ & $\begin{array}{l}-3.25^{6} \\
\left(2.75^{2}\right)\end{array}$ \\
\hline Observations & 700 & 700 & 697 \\
\hline
\end{tabular}

Robust standard errors in parentheses

**** $p<0.01$

** $\mathrm{p}<0.05$

* $\mathrm{p}<0.1$

of sexual violence compared to only $3 \%$ when there are no reports of sexual violence. However, if we also control for one-sided violence (model 2), i.e. the direct and deliberate killings of civilians, the effect is no longer significant. One-sided violence is not likely to be a confounder; instead, sexual violence and one-sided violence are probably better understood as different forms of violence an actor can engage in and alternate between. These findings suggest that one-sided violence is a better predictor of UN intervention than sexual violence. In Model 3 we disaggregate between sexual violence perpetrated by 
governments and rebels. Here we find that while sexual violence by rebels increases the likelihood of a UN intervention (although only at the go percent significance level), sexual violence by governments does not have an effect.

One challenge in evaluating how the Security Council responds to sexual violence is that we do not know what information was available to the decision makers at the time. Sexual violence is a vastly underreported phenomenon and the member states of the Security Council may have different information about the prevalence of sexual violence, depending on their local sources of information, as well as their varying interest in different conflicts and types of security threats. While the UN has developed mechanisms for monitoring and reporting information on sexual violence within the realm of a peacekeeping operation, such mechanisms are not in place before a mission has been established. Hence, for the decision to deploy a peacekeeping mission in the first place, the Security Council has to rely much on secondary sources.

The analysis so far has examined whether the Security Council responds to sexual violence reported by any of the following three sources: Us State Department, Amnesty International, and Human Rights Watch. These are the sources of the coding in the SVAC dataset. ${ }^{45}$ One advantage of that dataset is that it provides disaggregated information by the source of reporting. Table 3 provides a correlation matrix of these three variables, as well as the joint estimate used thus far in the analysis, which codes the highest value reported in any of the three. This shows that these three source variables are not highly correlated. Hence, the reporting of the occurrence of wartime sexual violence varies greatly across these three agencies. The joint estimate is highly influenced by the Us State Department, as these are correlated to 0.82 . The other two component variables have a lower impact since their correlations are

TABLE 3 How well do different sources of sexual violence correlate?

\begin{tabular}{lllll}
\hline & $\begin{array}{l}\text { SVAC } \\
\text { any source }\end{array}$ & SVAC & SVAC & SVAC \\
& & AI & HRW \\
\hline SVAC any source & 1.0000 & & & \\
SVAC USSD & 0.8240 & 1.0000 & & \\
SVAC AI & 0.6801 & 0.5635 & 1.0000 & 1.0000 \\
SVAC HRW & 0.6849 & 0.5701 & 0.5309 & \\
\hline
\end{tabular}

45 Cohen and Nordås, 'Introducing the svac Dataset'. 
lower. If we compare the different sources to each other, we see that they only correlate between 0.53 and 0.57 . What these numbers mean, more concretely, is that it will matter a great deal which source of information that the Security Council relies on when setting the policy agenda. Even if the member states are willing to respond to sexual violence, they may not be aware of on-going events. Hence, if we are interested in understanding whether the UN follows up on the protection agenda in the form of firm action through peacekeeping missions, we need to consider the dearth of information on sexual violence.

Due to this strong variation in what the different agencies report, we analyse how the Security Council responds to each different source of information on sexual violence. Table 4 presents these results. In Model 1, we look at the impact of sexual violence reported by the us State Department. The findings show that sexual violence by governments has a positive effect on UN intervention (at the 9o percent significance level), while sexual violence by rebels does not have a significant effect. Hence, we find the exact opposite from the model above when using the collapsed measure. This could be due to a stronger focus on repression and violations by state actors in the USSD reports, or it could be due to some other process that determines how the information in the USSD reports reaches the Security Council. What is important here is that it matters which source of information we use, as it yields completely opposite findings. In Model 2, we instead examine the impact of sexual violence as reported by Amnesty International. Since this is a strong advocacy organization, we could expect their reports to reach high-level policy makers. Results show that stateperpetrated sexual violence as reported by AI does not have an effect, but reports of sexual violence by rebels do increase the likelihood of a UN intervention. We find a similar pattern in Model 3, where we look at sexual violence as reported by the Human Rights Watch; also a strong advocacy voice, often with a strong focus on ingoing armed conflicts. We find a positive and significant effect of sexual violence by rebel groups as reported by HRW on the likelihood of peacekeeping deployment in the subsequent year, but no effect of state violence. The main coefficients for these models are plotted in Figure 2, which enables a more visual comparison of these variables. This illustrates the difference across the three sources in terms of direction and size, but it also clearly demonstrates how differently we would interpret the relative impact of state and rebel violence respectively depending on the source of information.

These differences are all the more apparent when we compare predicted probabilities based on the different models in Table 4. These are presented in Table 5. The estimated probability of a UN PKO due to high levels of sexual violence differs markedly depending on the source of information. Looking at the impact of state-perpetrated sexual violence, we get a very different picture 
TABLE 4 Comparing different reports of sexual violence

\begin{tabular}{|c|c|c|c|}
\hline Variables & $\begin{array}{c}(1) \\
\text { UN PKO }\end{array}$ & $\begin{array}{c}(2) \\
\text { UN PKO }\end{array}$ & $\begin{array}{c}(3) \\
\text { UN PKO }\end{array}$ \\
\hline State SV (USSD) ${ }_{t-1}$ & $\begin{array}{c}0.456^{*} \\
(0.273)\end{array}$ & & \\
\hline Rebel SV (USSD) ${ }_{\mathrm{t}-1}$ & $\begin{array}{c}0.373 \\
(0.229)\end{array}$ & & \\
\hline State $S V(A I)_{t-1}$ & & $\begin{array}{c}-0.187 \\
(0.363)\end{array}$ & \\
\hline $\operatorname{Rebel~SV}(A I)_{t-1}$ & & $\begin{array}{l}1.009^{* * *} \\
(0.376)\end{array}$ & \\
\hline State SV $(\mathrm{HRW})_{\mathrm{t}-1}$ & & & $\begin{array}{c}0.273 \\
(0.414)\end{array}$ \\
\hline Rebel SV $(\mathrm{HRW})_{\mathrm{t}-1}$ & & & $\begin{array}{l}0.886^{* * *} \\
(0.332)\end{array}$ \\
\hline Battle deaths $_{t-1}$ & $\begin{array}{c}0.155^{*} \\
(0.0892)\end{array}$ & $\begin{array}{c}0.137 \\
(0.0895)\end{array}$ & $\begin{array}{c}0.103 \\
(0.0954)\end{array}$ \\
\hline Population & $\begin{array}{c}-0.153 \\
(0.168)\end{array}$ & $\begin{array}{c}-0.118 \\
(0.169)\end{array}$ & $\begin{array}{c}-0.346 \\
(0.216)\end{array}$ \\
\hline Government conflict & $\begin{array}{c}0.480 \\
(0.485)\end{array}$ & $\begin{array}{c}0.428 \\
(0.499)\end{array}$ & $\begin{array}{c}0.670 \\
(0.567)\end{array}$ \\
\hline Rebel strength & $\begin{array}{l}0.534^{* *} \\
(0.215)\end{array}$ & $\begin{array}{l}0.555^{* * *} \\
(0.215)\end{array}$ & $\begin{array}{c}0.433^{* *} \\
(0.216)\end{array}$ \\
\hline Post-200o & $\begin{array}{c}-0.304 \\
(0.447)\end{array}$ & $\begin{array}{c}-0.239 \\
(0.429)\end{array}$ & $\begin{array}{c}-0.176 \\
(0.454)\end{array}$ \\
\hline Constant & $\begin{array}{c}-2.921 \\
(2.755)\end{array}$ & $\begin{array}{c}-3.289 \\
(2.810)\end{array}$ & $\begin{array}{c}0.899 \\
(3.657)\end{array}$ \\
\hline Observations & 687 & 667 & 471 \\
\hline
\end{tabular}

Robust standard errors in parentheses

**** $\mathrm{p}<0.01$

${ }^{* *} \mathrm{p}<0.05$

*p $<0.1$

if we use AI compared to USSD and HRW: with the former, the probability of a UN P KO is even lower with high levels of state sexual violence, compared to no such violence, whereas the probability more than triples with sexual violence as reported by the two latter. Turning to the impact of rebel-perpetrated sexual violence, instead, the probability is estimated to increase substantially from 


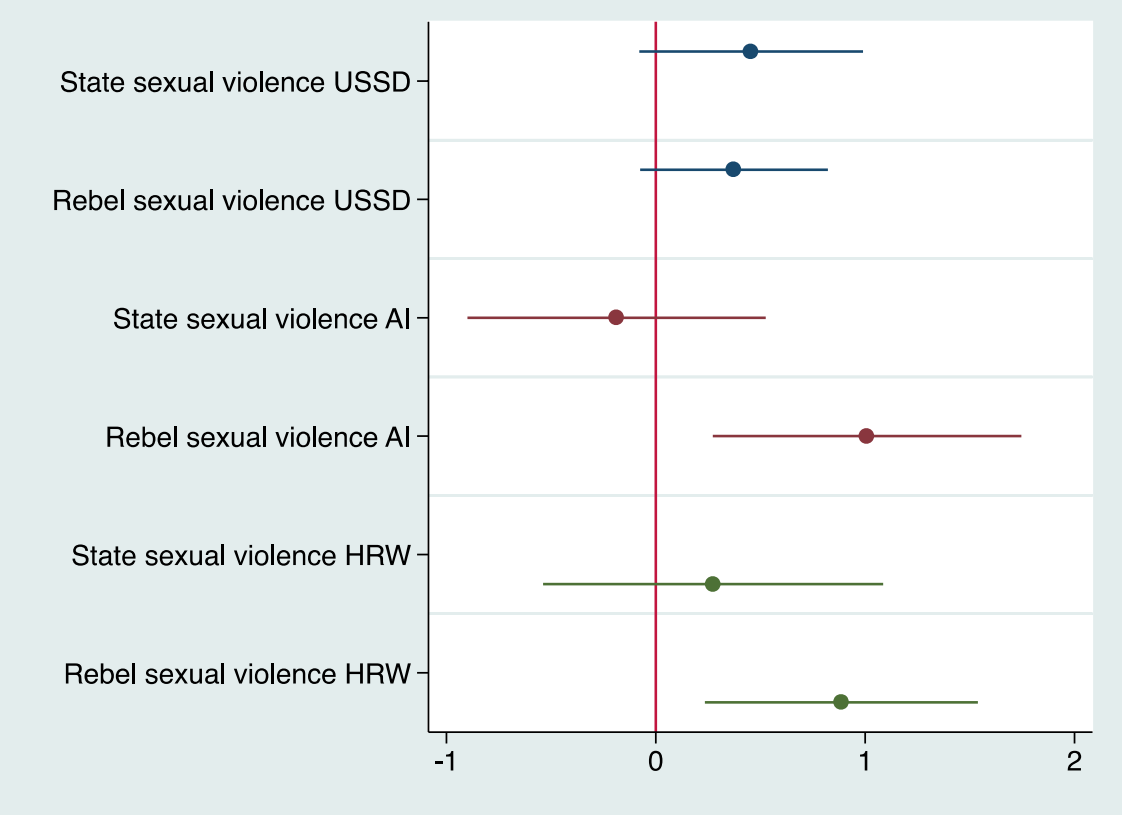

FIGURE 2 Coefficient plot, comparing the models from Table 4

TABLE 5 Predicted probabilities of a PKO onset using different measures of sexual violence

\begin{tabular}{lllll}
\hline & $\begin{array}{l}\text { No sexual } \\
\text { violence }\end{array}$ & $\begin{array}{l}\text { State sexual } \\
\text { violence }\end{array}$ & $\begin{array}{l}\text { Rebel sexual } \\
\text { violence }\end{array}$ & $\begin{array}{l}\text { Sexual violence } \\
\text { by both }\end{array}$ \\
\hline USSD & 0.037 & $0.15^{1}$ & 0.116 & 0.326 \\
AI & 0.043 & 0.035 & 0.488 & 0.367 \\
HRW & 0.050 & $0.15^{2}$ & 0.410 & 0.586 \\
\hline
\end{tabular}

Predictions for sexual violence set at 3 (=sexual violence reported as massive), continuous control variables set at their mean, other variables set at their median.

no violence to high levels as reported by AI and $\mathrm{HRW}$ - increasing from around 0.05 to between 0.41 and 0.49 . According to models using USSD data, however, there is not such a large impact - the probability only increases to about 0.12. These are very large differences.

Since we do not know what the true level of sexual violence was in the conflicts in the sample, we cannot say which source of information is the most 
appropriate. What we can say from these results are two things. First, it matters greatly which data source one uses, since they produce opposite findings. Second, we should examine more closely what information policy makers have access to when making policy. Formal documents, such as the UNSC resolutions establishing new missions or the meeting protocols from when those resolutions were adopted, sometimes refer to sexual violence as a problem that warrants the action of the UN, but they rarely specify the sources of such information. For example, when the mission to Sierra Leone, UNAMSIL, was established, the meeting referred to sexual violence at two instances, but with no reference to any report or explicit source of such violence. ${ }^{46}$ If we want to understand to what extent the protection norm from UNSCR1325 actually affects policy we need to understand what information policy making is based on. From the advocacy point of view, this is necessary if one wants to understand how to influence policy: should one influence the norms guiding the Security Council or should one rather ensure that they have access to better information of on-going cases of wartime sexual violence?

\section{Conclusions}

This paper examines UN peacekeeping and protection from sexual violence. While there has been an increase in attention to sexual violence, previous research has not yet examined whether the UNSC takes sexual violence into account when deciding to deploy peacekeeping missions. We ask whether the UN is more willing to intervene when there are reports of high levels of sexual violence. Our analysis indicates that there is a tendency of the UN to deploy peacekeepers to conflicts where there are higher levels of sexual violence. On average, this seems to be driven primarily by sexual violence perpetrated by rebel groups. Moreover, if we compare to the effect of direct killings of civilians, the latter is more strongly correlated with the initiation of a peacekeeping operation, which could be an indication of lethal violence receiving more information in media and thus pushing the Security Council to take action more firmly. Alternatively, it may be an indication that killings and sexual crimes are rated differently in terms of threats to international peace and security. Considering how well the R2P overlaps with the Women, Peace, and Security agenda in that they both emphasize protection from sexual violence, we could however have expected a stronger effect of sexual violence in driving the behaviour of the Security Council.

46 S/PV.4054, 22 October 1999. 
An important extension of our analysis is that we acknowledge the fact that wartime sexual violence is an underreported phenomenon that policy makers therefore have limited information about. We examine how our findings change if we assume that they get information from either one of three primary sources that report sexual violence. The findings suggest very different correlations between reported sexual violence and the onset of Un peacekeeping operations. While it is a very simplifying assumption that policy makers would only be informed by one source, our analysis raises questions about what type of information that policy makers have access to and what consequences this may have. For the protection agenda to have an effect on policy, policy makers need to be informed in real time about wartime sexual violence. 